\title{
Ev ile Yazı Arasında Mekik Dokuyan Denemeler: Nurdan Gürbilek'ten Ev Ödevi
} ARŞ. GÖR. AHMET DURAN ARSLAN*

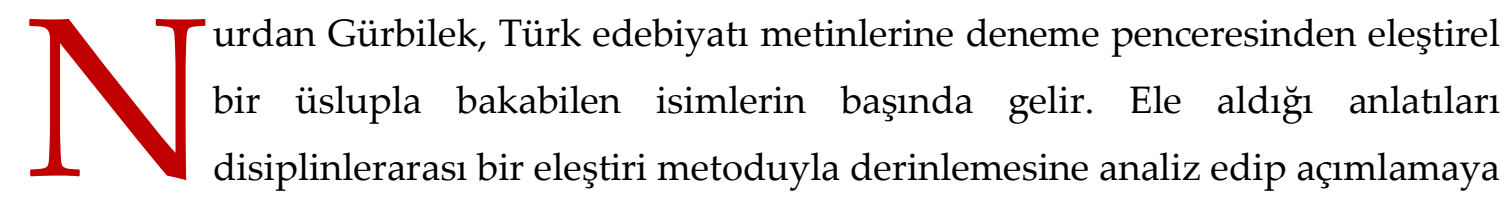
çalışan Gürbilek, kışkırtıcı sorular sorarak onlar üzerinde -alışılmışın dışında- muhtelif okuma, düşünme ve yorumlama yolları arar. 1980'li yılların Türkiye'sindeki kültürel zemini çözümlemeye çalıştığı ilk kitabı Vitrinde Yaşamak (1992) ile girdiği eleştirmenlik macerası, Yer Değgistiren Gölge (1995) ve Ev Ödevi (1999) ile devam eder. Türkiye'nin yakın tarihinde ön plana çıkmış kültürel imgeleri konu edindiği Kötü Çocuk Türk'ü (2001), edebiyat ve "endişe" kavramı arasındaki ilişkinin irdelendiği Kör Ayna, Kayıp Şark (2004) izler. Mağdurun Dili (2008), edebiyatı "mağduriyet" nosyonu çerçevesinde ele alan denemelerden oluşurken Benden Önce Bir Başkası (2011), bir yazarı başka bir yazarın ışığında okuyan yazılardan oluşur. Gürbilek'in son yayımlanan Sessizin Payı (2015) adlı kitabı ise sessizlik, konuş(a)ma(ma) ve adalet kavramları arasındaki bağlantıları çeşitli edebî metinler üzerinden tartışmaya açar. Bu çalışmada ise yukarıda bahsi geçen inceleme/eleştiri dizilerinden biri olan Ev Ödevi (1999) tanıtılacak ve kitapta sorunsallaştırılan ev ile yazı arasındaki ilişki tema ve yapı bakımından incelenecektir.

Ev Ödevi, beş bölümden ya da başka bir ifadeyle beş denemeden oluşur: "Oyun ve Adalet”, “Mırıltıdan Dile”, “Memur Çocukları-Ev Ödevleri-Pazar Öğledensonraları”, "Büyümenin Tarihi" ve "Kendine Ait Olmayan Oda". İlk dört bölümdeki denemelerin her birinde bir odak yazar ile karşılaşılır. Bu yazılarda merkeze alınan yazarlar farklı olsa da temanın ortak olduğu görülür. Yazıların hepsinde çocukluk deneyim ve hatıralarının içinde geçtiği mekân olan "ev"in yazma sürecine etkisi işlenir. "Kendine Ait Olmayan Oda" isimli son metinde de -birden çok yazara değinilmekle birlikte- aslında irdelenen mesele yine aynıdır: ev ile yazın dünyası arasındaki ilişki. Kitaptaki bölümlere daha yakından bakılacak olursa “Oyun ve Adalet” yazısının merkezî figürünün Oğuz Atay olduğu görülür. Daha çok Tutunamayanlar üzerine odaklanan metin, Atay'ın eserlerindeki mizah ve adalet duygusu temlerine vurgu yapar. Gürbilek, Atay'ın birbirine eklenmiş çeşitli seslerden, üst üste yı̆̆ılmış muhtelif söylem katmanlarından oluşan romanlarında mizahı bir "kaçış", "ardında

\footnotetext{
* Muğla S. K. Üniversitesi Edebiyat Fakültesi Türk Dili ve Edebiyatı Bölümü, ahmetduranarslan@gmail.com
} 
bırakma" ve "rahatlama" aracı olarak değil, tam tersine -metinsel düzlemde de olsa- bir adalet sağlama aracı olarak kullandığını belirtir. Ona göre Atay, parodiler aracılığıyla aslında Türk toplumunun azgelişmişliğinin/çocuk kalmışlığının hesabını sorup “yarımyamalakların hikâyesi"ni eleştirel bir tonda anlatır. Atay'ın eserlerindeki oyun ve adalet kavramları arasındaki ilişkiyi irdeleyen bu yazıya kuramsal çerçeve sağlayan temel kaynak ise Huizinga'nın Homo Ludens adlı kitabında yer alan mizah dolu adli oturumlardır.

“Mırıltıdan Dile” bölümünde odağa alınan yazar Latife Tekin'dir. Bu bölümde Tekin'in Sevgili Arsız Ölüm (1983) ve Berci Kristin Çöp Masalları (1984) gibi ilk dönem romanlarında bir dilsizlik ifadesi olarak yoksulluğu işlediği vurgulanır. Bu anlatıların, taşra ile kent arasında sıkışmış gecekondularda yokluk içinde var olma savaşı veren insanların kolektif sesini yansıttığı ifade edilir. Gürbilek'in belirttiği üzere Tekin, anlattığı hikâyelerde dünyayı hep ikiye ayırır: dilsizler ve dile hâkim olanlar. Dilsizler, mirıltı hâlinde kalıp dile gelememiş, saf, sade, sessiz ve çocuk kalmış insanlar; dile hâkim olanlar ise dil sayesinde kendilerine dışarıdan, başkalarına yukarıdan bakabilenlerdir. Bu bağlamda Gürbilek, Tekin'in metinlerinde dilin çoğu zaman eril bir alan olarak belirdiğini ifade eder. Ona göre bu alanın her zaman hâkimi değillerse de taşıyıcısı erkeklerdir; kadınların çoğu ise farklı bir dille, sanki gizli bir işaret

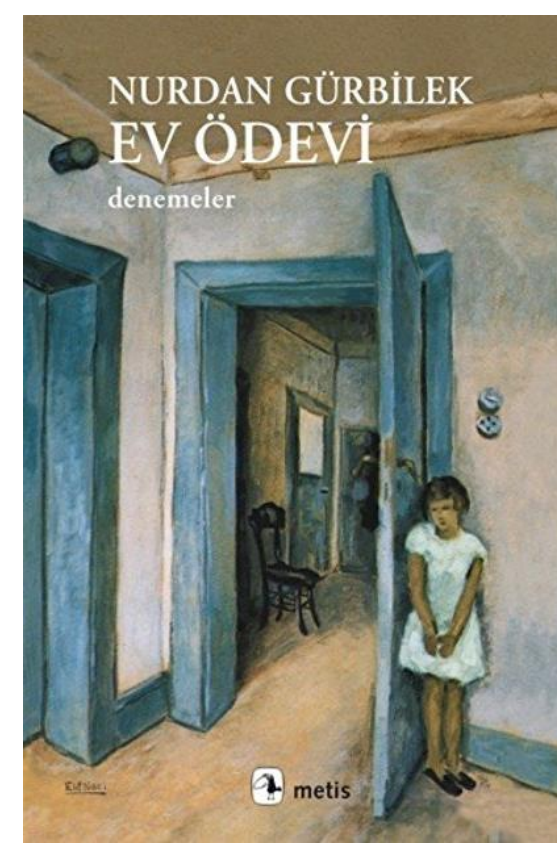
sistemiyle konuşurlar. Ayrıca yine bu bölümde Gece Dersleri (1986) romanının, Tekin'in yazarlığında bir kırılma noktası olduğu vurgulanır. Bu romanın, öncekilere nazaran dille daha çok oynayan, belirli sözdizim yapıları ile kalıplaşmış çeşitli ifadeleri aşan, biçimsel açıdan daha parçalı, dolayısıyla çok daha görsel bir metin olduğu belirtilir.

“Memur Çocukları-Ev Ödevleri-Pazaröğledensonraları” bölümünde Tezer Özlü’nün Çocukluğun Soğuk Geceleri (1980) kitabındaki ev ile yazı arasındaki ilişki çözümlenir. Gaston Bachelard'ın Mekânın Poetikası'nda bir "mutluluk mekânı" olarak çizilip "güvenli", "aydınlık" gibi olumlu sıfatlarla betimlenen "ev"in, Tezer Özlü'nün anlatısında farklı bir hüviyete büründüğü ve âdeta baskı ve tekinsizlik yüklü bir mekân olarak kurgulandığ 1 vurgulanır. Gürbilek, Özlü'nün cümlelerinin, anneden babadan kaçırılmış, kilit altında tutulan bir hatıra defterine düşülmüş ve onlara inat büyük bir açık sözlülükle yazıya dökülmüş notlara benzediğini belirtir. Kitaptaki dördüncü bölüm olan “Büyümenin Tarihi"nde ise merkeze alınan yazar Bilge Karasu'dur. Bu bölümde Karasu'nun metinlerinin dikkat çekici bir özelliğine yer verilir: Onun anlatılarının odağında başta hayvanlar olmak üzere deniz, bitki ve taş gibi insan-dışı varlıklar bulunur. Birçok edebiyat metninde ana anlatıya destek olması için sahne, dekor, arka plan vb. formlarda yardımcı eleman olarak kullanılan bu varlıklar, Karasu metinlerinin merkezine konumlanmıştır. Gürbilek, 
Karasu'nun Troya'da Ölüm Vardı (1963) ve Uzun Sürmüş Bir Günün Akşamı (1970) gibi ilk metinlerinde kanatıcılığı, yırtıcılığı ve yutuculuğu çağrıştıran hayvan imgesini bolca kullandığını ve eşitsizlik gerçeği üzerine kurulu, karanlık ve ürkütücü bir içeriği ele aldığını ifade eder. Göçmüş Kediler Bahçesi'nden sonra ise Karasu'nun masalsı ve yırtıcı hayvan imgesinden daha tanıdık ve evcil hayvan imgesine yöneldiğini savunur. Ona göre deşen, kemiren, parçalayan hayvanlar, yerlerini insanın birlikte yaşayabileceği, arkadaşlık kurabileceği hayvanlara bırakır. Dolayısıyla Karasu'nun metinlerinde bir ikiliğin, iki ayrı söylem biçiminin olduğu vurgulanır. Bu bölümde yazarın eserlerinde yinelenen bir temaya daha dikkat çekilir: Yaşını almış, görmüş geçirmiş, uslanmış kişiyle genç, toy, güzel olan arasındaki ilişki. İlki "usta" ya da "efendi", ikincisi ise "çırak" ya da "çocuk/acemi oğlan" şeklinde kurgulanmış bu ikili karşıtlıklar aracılığıyla aslında yine "eşitsizlik" kavramına vurgu yapıldığının altını çizer Gürbilek. Kitabın son bölümü olan "Kendine Ait Olmayan Bir Oda"da ise "odak-yazar" şeklindeki inceleme yönteminden uzaklaşılarak Türk edebiyatındaki temel modernist metinler üzerine daha bütüncül bir inceleme/değerlendirme girişimi başlatılır. Bu bağlamda Aylak Adam (1959), Tuhaf Bir Kadın (1971), Tutunamayanlar (1972), Ölmeye Yatmak (1973), Tehlikeli Oyunlar (1973) ve Çocukluğun Soğuk Geceleri (1980) gibi romanlardaki "ev" sorunsalı üzerinde durulur. Gürbilek bu romanların bir tür "evsizleşme anlatıları" olduğunu savunur. Ona göre bahsi geçen romanlardaki karakterlerin hepsi çocukluklarının geçtiği evlerle sorunları olan, onları bir sıkıntı ya da utanç kaynağı olarak kodlayan ve bu yüzden onlardan kaçmak isteyen bir görünüm sunarlar. Bu bölümde genel olarak, incelenen metinlerdeki ev betimlemeleri/çağrışımları üzerinden modernist edebiyattaki ev algısının saptanmaya çalışıldığı görülmektedir.

Nurdan Gürbilek'in Ev Ödevi'nin, yazı ile ev arasındaki ilişkiyi sorunsallaştıran, ikili arasındaki bağlantıları Türk edebiyatından çeşitli seçki metinler aracılığıyla ortaya koymaya çalışan bir dizi denemeden oluştuğunu söylemek mümkündür. Kitap, okuru geleneksel/yaygın kültürde daima "huzur", "güven” gibi olumlu çağrışımları olan "ev" kavramı üzerine yeniden düşünmeye davet eder. Geleneksel anlatılarda âdeta "cennetmekân" olarak çizilen "ev" kavramının, modernist anlatılarda bir "buhran-mekân"a dönüşümü odağa alınan muhtelif anlatılar üzerinden adım adım gösterilir. Ev Ödevi, ev ile yazı arasındaki bu devingen ilişkiyi ortaya koymasının yanı sıra, okuru eleştirel ve analitik düşünmeye sevketmesi itibarıyla da değerli bir deneme dizisi olarak betimlenmeyi hak etmektedir.

\section{Kaynakça}

Gürbilek, Nurdan (2014). Ev Ödevi. İstanbul: Metis. 